ischemia on known substrates and cofactors of the glycolytic pathway in brain. J Biol Chem 239:18-30

30. Holowach-Thurston J, McDougal DB 1969 Effect of ischemia on metabolism of the brain of the newborn mouse. Am J Physiol 216:348-352

31. Duffy TE, Kohle SJ, Vannucci RC 1975 Carbohydrate and energy metabolism in perinatal rat brain: relation to survival in anoxia. J Neurochem $24: 271$ 276

32. Vannucci RC, Duffy TE 1976 Carbohydrate metabolism in fetal and neonatal rat brain during anoxia and recovery. Am J Physiol 230:1269-1275

33. Magal E, Goldin E, Harel S, Yavin E 1988 Acute uteroplacental ischemic embryo: lactic acid accumulation and prostaglandin production in the fetal rat brain. J Neurochem 51:75-80
34. Lund-Andersen H 1979 Transport of glucose from blood to brain. Physiol Rev 59:305-352

35. Bachelard HS 1983 Transport of hexoses and monocarboxylic acids. In: Lajtha A (ed) Handbook of Neurochemistry, Vol 6, 2nd Ed. Plenum Press, New York, pp 339-354

36. Cremer JE, Cunningham VJ, Pardrige WM, Braun LD, Oldendorf WH 1979 Kinetics of blood brain barrier transport of pyruvate, lactate and glucose in suckling, weanling, and adult rats. J Neurochem 33:439-445

37. Daniel PM, Love ER, Pratt OE 1978 The effect of age upon the influx of glucose into the brain. J Physiol 274:141-148

\title{
Announcements
}

\section{Meeting Announcement}

The International Federation for Juvenile and Infantile Gynecology will hold its 10th World Congress of Pediatric and Adolescent Gynecology in Paris, France from May 21 through May 23, 1992. For further information and registration, contact: Convergences Gyn-Juv 92, 120 Avenue Gambetta, F-75020 Paris, France, FAX: (33) 1-40-31-01-65.

\section{9th Annual Seminar in Pediatric Nephrology}

The 19th Annual Seminar in Pediatric Nephrology; Current Concepts in Diagnosis and Management will be held February 9-13, 1992 at the Sheraton Royal Biscayne Beach Resort and Racquet Club, Key Biscayne, FL. For further information, contact: Jose Strauss, M.D., University of Miami School of Medicine, Department of Pediatrics, P.O. Box 016960, Miami, FL 33101, (305) 549-6726. 